\title{
THE EFFECTIVENESS OF THE GUIDED DISCOVERY LEARNING (GDL) METHOD USING A CONTEXTUAL APPROACH REVIEWED FROM MATHEMATICAL CRITICAL THINKING ABILITY OF SENIOR HIGH SCHOOL IN MUNA DISTRICT
}

\author{
Imaludin Agus'), Fitriani' ${ }^{2}$ \\ ${ }^{1)}$ Kendari State Islamic Institute, ${ }^{2)}$ Muhammadiyah Sinjai Islamic Institute \\ imal.udin@yahoo.co.id
}

\begin{abstract}
Abstrak
Penelitian ini bertujuan untuk menguji efektivitas metode pembelajaran penemuan terbimbing menggunakan pendekatan kontekstual dalam hal keterampilan berpikir kritis siswa SMP. Jenis penelitian yang digunakan adalah eksperimen semu. Populasi dalam penelitian ini adalah semua siswa kelas VIII Sekolah Menengah Atas di Kecamatan Kontukowuna, Kabupaten Muna, Sulawesi Tenggara pada tahun 2016/2017. Pengumpulan data diperoleh melalui penyediaan empat item pertanyaan instrumen tes keterampilan berpikir kritis, di mana setiap pertanyaan mewakili indikator kemampuan berpikir kritis dan lembar observasi pelaksanaan pembelajaran. Hasil penelitian dianalisis menggunakan uji t satu sampel. Temuan menunjukkan bahwa nilai uji t 2,719> $\left(\mathrm{t} \_0,05,27\right)=2,0518$, yang dapat disimpulkan bahwa metode pembelajaran penemuan terbimbing efektif dalam hal kemampuan berpikir kritis siswa SMP. Hasil ini didukung oleh peningkatan rata-rata pretest 27,66 ke posttest 76,00 yang lebih tinggi dari kriteria penguasaan mengajar minimum (KKM) dari 70 .
\end{abstract}

Kata kunci: pembelajran discovery, kontekstual, berpikir kritis, matematika

\begin{abstract}
This study aimed to test the effectiveness of guided discovery learning method using a contextual approach in terms of students' critical thinking skills of SMP. Type of research used was quasi experiment. Population in this research was all VIII grader students of Senior High School in sub-district Kontukowuna, Muna districts, Southeast Sulawesi in 2016/2017. Data collection was obtained through the provision of four items of question of critical thinking skills test instrumen, where each question represents an indicator of critical thinking ability and observation sheet of learning implementation. Research result was analyzed using one sample $t$ test. The findings showed that $t$ test value $2,719>\left(t_{0.05}, 27\right)=2.0518$, which can be concluded that the guided discovery learning method was effective in terms of the critical thinking ability of junior high school students. This result was supported by the increase of average of pretest 27.66 to posttest 76.00 which was higher than the minimum teaching mastery criteria (KKM) of 70 .
\end{abstract}

Keywords: discovery learning, contextual, critical thinking, math

Sitasi: Agus, I. dan Fitriani. 2019. The Effectiveness of The Guided Discovery Learning (GDL) Method Using a Contextual Approach Reviewed from 
Mathematical Critical Thinking Ability of Senior High School in Muna District. Matematika dan Pembelajaran, 7(1), 22-34.

\section{INTRODUCTION}

Mathematics has an important role in the development of science and technology. Mathematics is not only seen as an abstract science that contains symbols, numeric, and formulas, but becomes a universal language for every science. As Van de Walle, Karp \& Bay-Willams (2010: 102) states that mathematics is a universal language and is the foundation for the advancement of modern science and technology.

Mathematics is also a knowledge that accommodates students' thinking abilities, one of which is the ability to think critically. This is supported by Smith's opinion (Chambers \& Timlin, 2013: 7) and Minister of Education and Culture Regulation (2006) which states that mathematics learning contains the ability to think analytically, analogically, creatively, critically and think logically. The description confirms that mathematics and the ability to think critically are two things that cannot be separated. As the results of research written by Jacob (2012); Fatemen (2014) and Tajudin \& Chinnapan (2016) concluded that critical thinking skills have correlations that are directly proportional to students' mathematical achievements.

Critical thinking is an action in assessing an argument / problem and choosing a resolution strategy from the argument / problem (Feldman, 2010: 4). Critical thinking is also interpreted as reasonable thinking and focuses on the best decisions produced (Fisher, 2009: 10; Ennis, 2011: 1; \& Tittle, 2011: 4). Therefore, critical thinking is concluded as a reasonable thought to realize the right decision making.

In relation to critical thinking skills, many references state that critical thinking skills involve the process of conceptualization, application, analysis, synthesis, and evaluation (Peter, 2012: 39; Lau, 2011: 2; Ennis, 2011: 1; Facione, 2011: 5- 7; and Glazer, 2001: 68). More specifically in mathematical critical thinking skills, Glazer (2001: 68) has 4 components, namely support, inference, clarification, and strategy. Based on the various descriptions, the aspects of 
mathematics critical thinking skills in this study consist of interpretations, analysis, evaluation, and inference (conclusions). This capability is an important aspect that students must have as a guideline in selecting various problem solving strategies faced.

However, the facts show that students' critical thinking skills in junior high school have not accommodated students in developing critical thinking skills, this is indicated by the mechanistic learning system in the classroom (Mahmudi, 2009). In addition, according to the results of a study by the Trends of the International Mathematics and Science Study (TIMSS) in 2011, the ability of Indonesian students only revolves around factual and procedural mathematical questions (Mullis, 2011). This further confirms that students in Indonesia have not been trained in the process of solving mathematical problems that involve critical thinking skills.

The results of the pre-study conducted in several State Junior High Schools in Muna Regency showed that mathematics learning in class students had not yet reflected the accommodation of students' critical thinking skills. This is indicated by the passivity of students during the learning process (teacher oriented). In addition, the learning material applied is textual and problem exercises. Likewise the applied learning method has not been able to involve active students and understand the benefits of learning material in class and daily life. This condition is contrary to the goal of 21 st century mathematics learning which requires students to actively construct their knowledge through communication, collaboration, critical thinking, and creative activities (Marsigit, Rizkianto, \& Murdiyani, 2015: 225).

Addressing various facts and problems that have been described, then an alternative solution is needed in the form of experimentation on the use of methods and approaches to learning mathematics with the aim of developing and improving students' critical thinking skills. The method is oriented towards students and is able to show the relationship of each material learned in class and its use in daily life. The learning method in question is guided discovery learning (GDL).

Eggen \& Kaucak (2010: 128) GDL is a learning method that begins with the 
teacher giving an example to illustrate the sub-study of the material being studied. Similarly, Baroody, Purpura, Eiland (2014: 2) states that GDL involves students in the process of forming patterns, relationships, and strategies. This method is very potential to improve critical thinking, because each learning syntax contains activities that can stimulate each indicator of critical thinking skills. The syntax of the GDL in question is (1) stimulus; (2) identification of problems; (3) collecting data; (4) analyze data; (5) verification; and (6) conclude (Shah, 2014; Westwood, 2008; \& Markaban, 2006).

In addition to the GDL method, so that students can see the relationship between mathematical material and real life, a relevant learning approach is needed. The learning approach is a contextual or CTL approach. CTL is a learning approach that helps students see the relevance of material with real life so as to encourage students to know the implementation in life (Clemete \& Vesta, 2010; Sanjaya, 2016). CTL itself has advantages in the meaningfulness of learning and fosters students' critical thinking skills (Jhonson, 2014). The syntax of the CTL approach used refers to the opinion of Crawford (2001), namely relating, experiencing, applying, cooperating, and transfering.

Based on these two explanations, in this study integrating the GDL method using the CTL approach which gave birth to the syntax of integration between the GDL methods using the CTL approach. The perpendicular syntax is as follows: (1) relating, this stage is used to observe each contextual problem that is relevant to the material provided; (2) cooperating, this stage students carry out cooperation and communication; (3) Problem Identification, at the stage where activities are identified to identify various information; (4) Experiencing, used to find and write down all relevant information; (5) Data Analysis, this stage is used to analyze all information that has been obtained; (6) Verification, used to review every information obtained; (7) conclusions, used to conclude their observations formally; (8) applying, this stage is used to utilize the findings; and (9) transfering, at this stage there is a transfer process and using the knowledge gained into different problems. 
The combination can theoretically have the potential to improve students' mathematical critical thinking skills. Similarly, empirically, the research conducted by (Siregar \& Marsigit, 2015; Imawan, 2005; \& Mustafa, 2014) concluded that GDL can improve student achievement and critical thinking skills. Separately for the CTL approach, research conducted by (Kurniati, 2015; and Putri \& Santosa, 2015) concludes CTL the same thing.

Although, research on the application of the GDL method and the CTL approach has been partially carried out by several parties in improving students' mathematical critical thinking skills. However, this study combines the two methods and approaches with the aim of improving students' mathematical critical thinking abilities. In addition, studies using the GDL method and the CTL approach have not been implemented at the SMP in Muna District, especially the SMP in Kontukowuna, where students are capable of critical thinking. Thus the experimentation researcher carried out the title "the effectiveness of the guided discovery learning method using a contextual approach in terms of junior high school students' critical thinking skills".

\section{METHOD}

The research is a type of all experimental research (quasi experiment). This type of research was chosen on the grounds that not all factors can be controlled (Creswell, 2012). The research design used was nonequivalent pretest-posttest control-group design, where at the beginning of the activity the pretest was given the ability to think critically to find out the students' initial abilities, then treatmant in the form of the GDL method using the CTL approach, and ended with posttest.

This research was conducted at Muna Kontukowuna Middle School, Southeast Sulawesi Province in 2017 for class VIII students for 12 meetings. The implementation in detail is 2 meetings at the beginning and at the end, used for the pretest and posttest activities, and for the other 10 meetings used as treatmant activities. The instrument used was the test instrument for students' mathematical critical thinking skills and the learning implementation observation sheet. 
The instrument of critical thinking ability test consists of 4 description questions that represent each indicator. The instrument used was first tested for validity and reliability estimation. The validity test used is in the form of content validity test conducted by 2 experts in the field of mathematics, while the reliability estimation is obtained at 0.665 for the pretest and 0.674 for the posttest. These results indicate that the instruments used are good (reliable) (Ebel \& Frisbe, 1991). The grids of critical thinking skills are presented in the following Table 1:

Table 1. Grid of Instruments for Critical Thinking

\begin{tabular}{|c|c|c|}
\hline No & Aspect & Indicator \\
\hline 1 & Interpretation & $\begin{array}{l}\text { Revealing the adequacy } \\
\text { of information }\end{array}$ \\
\hline 2 & Analysis & $\begin{array}{l}\text { Analyze relevant } \\
\text { arguments and logical } \\
\text { reasons }\end{array}$ \\
\hline 3 & Evaluation & $\begin{array}{l}\text { Assess the truth of an } \\
\text { argument }\end{array}$ \\
\hline 4 & Inference & $\begin{array}{l}\text { Draw conclusions from } \\
\text { an argument }\end{array}$ \\
\hline
\end{tabular}

While for the learning implementation observation sheet refer to the syntax of GDL learning using the CTL approach which starts from (1) relating; (2) cooperating; (3) identify problems; (4) experiencing; (5) analyze data; (6) verify; (7) conclude; (8) applying; and (9) transfering.

The research data were analyzed using descriptive and inferential analysis. Descriptive analysis consisted of mean, presentation, variance, max, min, and standard deviation, while inferential analysis used the one sample $t$ test (Steven, 2011). The GDL learning method using the CTL approach is effective in terms of students' critical thinking skills with criteria for completeness 70 . The research hypotheses tested are as follows: 
$\mathrm{H}_{0} \quad: \mu \leq 69,9 \quad \& \quad \mathrm{H}_{\mathrm{a}} \quad: \mu>69,9$

\section{RESULT AND DISCUSSION}

This research was carried out in state junior high schools in Muna Regency precisely in Kontukowuna District from February 14 to March 25, 2017. The study began with giving pretest questions of critical thinking skills, followed by 10 material meetings, and ended with posttest mathematical critical thinking skills . Based on the observation sheet of the implementation of learning in the class, the average value of the percentage of implementation of GDL learning was obtained using the CTL approach which was $97.3 \%$. These results indicate that the learning has been carried out in accordance with the stages of the learning plan prepared.

In relation to the data on students' mathematical critical thinking skills, descriptively for the pretest and posttest data the results were obtained as presented in Table 2 below:

Table 2. Pre-Post Critical Thinking Data

\begin{tabular}{lcc}
\hline \multirow{2}{*}{ Description } & \multicolumn{2}{c}{ GDL-CTL } \\
\cline { 2 - 3 } & Pre & Post \\
\hline Mean & 27,66 & 76,00 \\
Stdv & 16,21 & 11,69 \\
Var & 262,69 & 136,76 \\
Maks & 59,38 & 96,88 \\
Min & 9,37 & 46,88 \\
Completeness & $0 \%$ & $89,29 \%$ \\
\hline
\end{tabular}

Based on descriptive analysis presented in Table 2 shows that the average value of mathematical critical thinking skills has increased from pretest to posttest. The average value of the pretest of mathematical critical thinking skills of 27.66 increased to 76.00 in the posttest, with presentation completeness of $0 \%$ at the pretest increased to $89.29 \%$ (25 students) who completed the posttest. These results 
indicate that the average value of students has reached the specified criteria for completeness, namely 70 . This means that the GDL learning method using the CTL approach effectively improves students' mathematical critical thinking skills.

In addition to describing the overall score of student acquisition, the data from the pretest and posttest were also described as the average score of students for each aspect of critical thinking skills. The average score of each aspect of students' critical thinking skills can be seen in Table 3 below:

Table 3. Data on Aspects of Critical Thinking

\begin{tabular}{lccc}
\hline \multirow{2}{*}{ Aspect } & \multicolumn{3}{c}{ GDL-CTL } \\
\cline { 2 - 4 } & Pre & Post & Pnkt \\
\hline \multirow{4}{*}{ Interpretation } & 3,26 & 6,71 & 3,45 \\
& $(40,74$ & $(83,93$ & $(43,19$ \\
& $\%)$ & $\%)$ & $\%)$ \\
\hline \multirow{4}{*}{ Analysis } & 1,19 & 7,5 & 6,31 \\
& $(14,81$ & $(93,75$ & $(78,94$ \\
Evaluation & $\%)$ & $\%)$ & $\%)$ \\
\hline \multirow{4}{*}{ Inference } & 2,52 & 4,64 & 2,12 \\
& $(31,48$ & $(58,04$ & $(26,56$ \\
& $\%)$ & $\%)$ & $\%)$ \\
\hline & 1,89 & 5,46 & 3,56 \\
& $(23,61$ & $(68,3 \%)$ & $(44,69$ \\
& $\%)$ & & $\%)$
\end{tabular}

Based on Table 3 the results obtained for each aspect of critical thinking skills have increased when the GDL learning method has been applied using a contextual approach. In the aspect of interviewing, there was an increase of $3.45(43.19 \%)$, the analyzing aspect had an increase of 6.31 (78.94\%), the evaluating aspect had an increase of $2.12(26.56 \%)$, and the concluding aspect experienced an increase of $3.56(44.69 \%)$.

Not only that, to see the effectiveness of the GDL learning method using the 
Contextual Approach reviewed from Critical Thinking Ability, the One Sample $t$ Test was also conducted. The test results obtained t value of 2.719> $\left(\mathrm{t} \_0.05 .27\right)=$ 2.0518 which means that $\mathrm{H}_{-} 0$ is rejected. With the rejection of $\mathrm{H}_{-} 0$, it can be concluded that the GDL learning method uses an effective contextual approach in terms of the ability to think critically.

Guided discovery learning methods using a contextual approach have a positive impact on improving students' mathematical critical thinking skills. This is based on the results of the descriptive analysis obtained an average increase of 48.34 from pretest of 27.66 to 76 in the posttest, with completeness of $0 \%$ at the pretest to $89.28 \%$ (25 students) at the posttest. Similarly, in terms of each aspect of critical thinking skills, where for the aspect of interpretation obtained a value of 3.26 $(40.74 \%)$ at pretest increased by $3.45(43.19 \%)$ to $6.71(83.93 \%)$ in posttest, analyzing aspects obtained a value of $1.19(14.81 \%)$ at the pretest increased by 6.31 $(78.75 \%)$ to $7.5(93.75 \%)$ in the posttest, the evaluation aspect obtained a value of $2.52(31.48 \%)$ at the pretest increased by $2.12(26.56 \%)$ to $4.64(58.04 \%)$ in the posttest, and the concluding aspect obtained a value of $1.89(23.61 \%)$ at the pretest increase amounting to $3.56(44.69 \%)$ to $5.46(68.3 \%)$ in the posttest. This is also supported by the results of the one sample $t$ test with a $t$ value of $2.7169>\mathrm{t}$ table $=$ 2.0518 , therefore H_0 is rejected. It means that guided discovery learning method uses an effective contextual approach in terms of students' mathematical critical thinking abilities.

The application of the GDL learning method using a contextual approach has a significant influence on students' mathematical critical thinking abilities. This increase occurs because the characteristics and stages of the method can accommodate the improvement of students' mathematical critical thinking skills. In the GDL learning method students become the main factor determining the success of learning, where students make discoveries independently or in groups, so knowledge is obtained through its own construction. The role of the teacher in the GDL method is only as a facilitator, mediator, or motivator. In line with that, Cruickshank, Jenkis \& Metcalf (2012: 271) states that the characteristics of the 
discovery method are the involvement of students in exploring and thinking, so that they can improve cognitive levels, one of which is critical thinking.

In general, if viewed from the stages of the GDL method consisting of stimulus, problem identification, analysis, and conclusions direct students to be able to explore their ideas. As, Westwood (2008: 29) states that in the GDL method the teacher helps students to be able to connect their ideas. This characterizes a critical thinker, as opinion (Lau, 2011: 2). This opinion is also supported by the results of research conducted by Yuliani and Saragih (2015) which concluded that "critical thinking mathematically abilities with guided discovery models more varied and better". In addition, each stage of GDL has strong relevance to every aspect of students' mathematical critical thinking abilities. For example "inference aspects (conclusions) have a significant increase because in the GDL stage there are concluding stages". Likewise with the aspect of analysis, evaluation can be accommodated by stages of GDL such as the stages of data analysis and verification.

This is also supported by a contextual approach, where the stages begin with relating to train students' critical thinking skills, especially in terms of interpretation. In addition, stages such as cooperating, experiencing and transfering have strong relevance to accommodate students' critical thinking skills. As Jhonson (2014: 65) states that the characteristic of a contextual approach is to accommodate student involvement in critical thinking. In connection with that, Sanjaya (2016: 265) states that the inquiry component in a contextual approach makes students trained in thinking. This is supported by the results of research conducted by Syahbana (2012: 53) which concluded that there was a significant increase in students' critical thinking skills by applying a contextual approach. Similarly, Kurniati, et al. (2015) that CTL learning effectively improves students' mathematical critical thinking skills. This opinion is reinforced by Moore's opinion (2012: 8) that in learning students will construct and build their own knowledge through experience and interaction with their learning environment.

Based on these reviews, it is increasingly confirmed that guided discovery 
learning (GDL) learning methods use an effective contextual approach in terms of students' mathematical critical thinking abilities. Therefore, combining the GDL method and contextual approach can be an alternative to developing students' thinking skills, especially in mathematics learning and solving mathematical problems, so that it has implications for every problem solving in daily life.

\section{CONCLUSION}

Based on the results of the research and discussion presented, it can be concluded that the GDL method uses an effective contextual approach in terms of students' mathematical critical thinking abilities. This is shown by the average value of the increase in pretest to student posttimes of 27.66, increasing to 76.00 higher than the KKM criteria of 70. In addition, based on the results of the $t$ test, the $t$ value is $2.719>\left(\mathrm{t} \_0.05 .27\right)=2.0518$ which means that $\mathrm{H}_{-} 0$ is rejected. With the rejection of H_0, it can be concluded that the GDL learning method uses an effective contextual approach in terms of the ability to think critically.

\section{Recommendations}

Based on these disclosures, researchers can recommend the use of the GDL learning method using a contextual approach (CTL) to facilitate accommodating students' critical thinking skills. In addition, you can also use these methods to improve other cognitive abilities.

\section{REFERENCES}

Abdillah. (2017). Prediksi Nilai Mata Kuliah Mahasiswa Berdasarkan Nilai Raport, Pretest, dan Motivasi Belajar. Matematika dan Pembelajaran, 5(2), 121140.

Baroody, A. J, Purpura, D. J, Eiland, M. D, \& Reid, E. E. (2014). The Impact of Highly and Minimally Guided Discovery Instruction on Promoting the Learning of reasoning Strategies for Basic add-1 and doubles Combinations. Early Childhood Research Quarterly. http://dx.doi.org/10.1016/j.ecresq.2014.09.003

Chambers, P \& Timlin, R. (2013). Teaching Mathematics in the Secondary School. New Dehli: Sage Publications.

Clemete, C. H \& Vesta. (2010). Contextual Teaching and Learning for Practitioners. 
Systemics, Cybernetics and Informatics, 6(4), 54-58.

CORD. (1999). Teaching Science Contextual the Cornerstone of Tech Prep. Texas: CORD Communications, Inc.

Crawford, M. L. (2001). Teaching Contextually: Research, Rationale, and Techniques for Improving Student Motivation and Achievement in Mathematics and Science. Waco, Texas: CCI Publishing.

Creswell, J. W. (2012). Research Design (Pendekatan Kualitatif, Kuantitatif, dan Mixed). (Terjemahan Achmad Fawaid). Yogyakarta: Pustaka Belajar.

Cruickshank, D. R, Jenkins, D. B, \& Metcaft, K. K. (2012). The Act of Teaching $\left(\sigma^{\text {th }}\right.$ ed). New York: McGraw-Hill.

Eggen, P \& Kauchak, D. (2010). Educational Psychology Windows on Classrooms $\left(8^{\text {th }}\right.$ ed). New York: Pearson Educational.

Ennis, R. H. (2011). The Natural of Critical Thinking: An Outline of Critical Thingking Disposition and Abilities. Sixth International Conference on Thinking at MIT.

Facione, P. A. (2011). Critical Thinking: What It Is and Why It Counts. Englewood Cliffs: Pearson Education.

Feldman, D. (2010). Berpikir Kritis Starategi Pengambilan Keputusan. Jakarta: PT Indeks.

Fisher, A. (2009). Berpikir Kritis Sebuah Pengantar. New York: Cambridge University Press. (Buku asli diterbitkan tahun 2007).

Glazer, E. (2001). Using Web Sources to Promote Critical Thinking in High School Mathematics. University of Georgia, United States of Americ, 67-71.

Imawan, O. R. (2015). Perbandingan antara Keefektifan Model Guided Discovery Learning dan Project-Based Learning pada Matakuliah Geometri. Pythagoras: Jurnal Pendidikan Matematika, 10(2), 179-188.

Jacob, S.M. (2012). Mathematical achievement and critical thinking skills in asynchronous discussion forum. Procedia - Social and Behavioral Sciences, $31,800-804$.

Jhonson, E. B. (2014). Contextual Teaching and Learning Menjadi Kegiatan Belajar-Mengajar Mengasikan dan Bermakna. (Terjemahan Ibnu Setiawan). California: Corwin Press. (Buku asli diterbitkan tahun 2002).

Kurniati, Kusumah. Y. S, Sabandar, J, \& Herman, T. (2015). Mathematical Critical Thinking Ability Through Contextual Teaching and Learning Approach. IndoMS-JME, 6(1), 53-62.

Lau, J. Y. (2011). An Introduction to Critical Thinking and Creativity Think More, Think Better. Canada: John Wiley \& Sins Inc.

Mahmudi, A. (2009). Mengembangkan Kemampuan Berpikir Siswa melalui Pembelajaran Matematika Realistik. Seminar Nasional Penelitian, Pendidikan dan Penerapan MIPA (pp. 349-354). Yogyakarta: MIPA UNY.

Markaban. (2006). Model Pembelajaran Matematika dengan Pendekatan Penemuan Terbimbing. Yogyakarta: Pusta Pengembangan dan Penataran Guru Matematika Yogyakarta.

Marsigit, Rizkianto. I \& Murdiyani, N. M. (2015). Filsafat Matematika dan Praktis Pendidikan Matematika. Yogyakarta: UNY Press. 
Moore, K. D. (2012). Effective Instructional Strategis: From theory and practice. New York: Rountledge.

Mullis. A, Martin. M, Foy. P, \& Arora. A. (2012). TIMSS 2011 International Results in Mathematics. Boston: TIMSS \& PIRLS International Study Center.

Mustafa, A. N. (2014). Upaya Meningkatkan Kemampuan Berpikir Kritis dan Kreatif serta self-effcacy dalam Pembelajaran Matematika melalui Discovery Learning. Tesis Magister, tidak diterbitkan, Universitas Pendidikan Indonesia, Bandung.

NCTM. (2000). National Council of Teachers of Mathematics (NCTM). New York: NCTM. Diambil kembali dari www.nctm.org.

Peter, E. E. (2012). Critical thinking: Essence for teaching mathematics and mathematics problem solving skills and mathematics problem solving skills. African Journal of Mathematics and Computer Science Research, 5(3), 39-43.

Putri, R. I \& Santosa, R. H. (2015). Keefektifan Strategi REACT ditinjau dari Prestasi Belajar, Kemampuan Penyelesaian Masalah, Koneksi Matematis, Self Efficacy. Jurnal Riset Pendidikan Matematika, 2(2), 262-272.

Siregar, N. C \& Marsigit. (2015). Pengaruh Pendekatan Discovery Yang Menekankan Aspek Analogi Terhadap Prestasi Belajar, Kemampuan Penalaran, Kecerdasan Emosional Spiritual. Jurnal Riset Pendidikan Matematika, 2(2), 224-234.

Syahbana, A. (2012). Peningkatan Kemampuan Berpikir Kritis Matematis Siswa Smp Melalui Pendekatan Contextual Teaching And Learning. Edumatica, 2(1), 45-57.

Tittle, P. (2011). Critical Thinking An Appeal to Reason. New York: Routledge.

Van de Walle, J. A, Karp, K. S, \& Bay-Williams, J. M. (2010). Elementry and Middle School Mathematics Teaching Developmentally $\left(7^{\text {th }}\right.$ ed). Boston: Pearson.

Westwood, P. (2008). What Teachers Need to Know About Teaching Metods. Cambera: Acer Press.

Yuliani. K \& Saragih. S. (2015). The Development of Learning Devices Based Guided Discovery Model to Improve Understanding Concept and Critical Thinking Mathematically Ability of Students at Islamic Junior High School of Medan. Journal of Education and Practice, 6(24), 116-128. 